\title{
Dying to be big: a review of anabolic steroid use
}

\author{
H. M. Perry MB, D. Wright MFPHM and B. N. C. Littlepage FFPHMI \\ Department of Public Health Medicine, Swansea, UK
}

\begin{abstract}
Anabolic steroids use is commonly perceived to be the domain of the higher echelons of competitive athletes. However, a great deal of anabolic steroid use occurs in private gymnasia (non-local authority) among noncompetitive recreational athletes. Our study has attempted to give an insight into the prevalence of the use of these drugs, the hazards associated with it, and the public health responses which we have adopted.
\end{abstract}

Keywords: Anabolic steroids, needle exchange schemes

The use of anabolic steroids is perceived by the media, by sports physicians and athletic communities to have reached phenomenal proportions during the last few years. However, the prevalence is poorly documented in the literature and relates mostly to North America. For example, in 1973 at five American universities, $1.5 \%$ of the general college population, including women, were users of anabolic steroids ${ }^{1}$. In 1975, anabolic steroid abuse among the general population in Arizona high schools was found to be $0.7 \%$ and there is a $4 \%$ use rate among athletes at these schools ${ }^{2}$. A later study, in 1986, showed that the rate of current and previous anabolic steroid use was $3 \%$ for all students polled at an institution in Minneapolis ${ }^{3}$. One of the latest studies recorded in the literature in 1988 suggested that $6.64 \%$ of senior male students use or have used anabolic steroids ${ }^{4}$, and it is also probable that there was a certain amount of under-reporting.

It is a well-known hypothesis, but not documented, that the élite athletes may be the smallest but most visible user group and that a larger user group exists that is composed of lower-level recreational individuals with other reasons for use, mostly physical appearance.

This study was designed to help establish the prevalence of anabolic steroid drug misuse among people using gymnasia on a regular basis (three or more times per week) in West Glamorgan. The impetus for the development of this study was provided by much anecdotal evidence from people using gymnasia, and those operating the needle exchange scheme within West Glamorgan who suggest that anabolic steroid use is much more widespread than previously thought.

Address for correspondence: Dr H. M. Perry, Department of Public Health Medicine, West Glamorgan Health Authority, 36 Orchard Street, Swansea SA1 5AQ, UK

(C) 1992 Butterworth-Heinemann Ltd 0306-3674/92/040259-03

\section{Subjects and methods}

A questionnaire was employed to collect data on prevalence and patterns of anabolic steroid use.

Questionnaires were distributed to private gymnasia. The questionnaires were given to attenders on entry to the establishment, to fill in when convenient. An envelope was provided in which the form should be placed when completed and deposited in a collection box at the establishment's reception area.

The questionnaire was designed to have simple questions, and used vocabulary and terms familiar to the target population. There were 16 questions, with options provided and also an opportunity to list alternative responses if the options provided were not suitable.

It should be made clear at this point that three privately owned gymnasia expressed a wish not to participate in this study.

\section{Results}

One has to appreciate the difficulties involved in making an assessment of the denominator. This is because, with privately owned gymnasia, the people attending are usually not formally registered and pay for attendance either on a weekly, monthly or yearly basis, so the difficulties in making the assessment of total numbers using the facility concerned can be appreciated. This assessment was provided by the gymnasium owner or manager.

\section{Private gymnasia}

Out of an estimated population sample of 300 people, 160 responses were received, a $53.3 \%$ response rate. Of the 160, 62 admitted having taken steroids $(38.8 \%)$. Reasons for training are given in Table 1, and

Table 1. Reasons for weight training

\begin{tabular}{lrrrrr}
\hline & \multicolumn{2}{c}{$\begin{array}{c}\text { Private } \\
\text { gymnasia } \\
\text { users }\end{array}$} & & \multicolumn{2}{c}{$\begin{array}{c}\text { Private } \\
\text { gymnasia } \\
\text { steroid users }\end{array}$} \\
\cline { 2 - 3 } $\begin{array}{l}\text { Type of } \\
\text { training }\end{array}$ & Total & $\%$ & & Total & $\%$ \\
\hline $\begin{array}{l}\text { Body-building } \\
\text { Power-lifting }\end{array}$ & 90 & 56.3 & & 44 & 71.0 \\
$\begin{array}{l}\text { Weightlifting } \\
\text { Fitness }\end{array}$ & 15 & 9.4 & & 7 & 11.3 \\
Other & 7 & 4.4 & & 4 & 6.5 \\
Total & 46 & 28.8 & & 7 & 11.3 \\
\hline
\end{tabular}


Table 2. Age distribution of responders in private gymnasia

\begin{tabular}{lrrrrr}
\hline & \multicolumn{2}{c}{$\begin{array}{c}\text { No. using } \\
\text { private } \\
\text { gymnasia }\end{array}$} & & \multicolumn{2}{c}{ Steroid users } \\
\cline { 2 - 6 } Age & Total & $\%$ & & Total & $\%$ \\
\hline Under 20 & 6 & 3.8 & & 0 & \\
$20-24$ & 46 & 28.8 & & 20 & 32.3 \\
$25-29$ & 48 & 30.0 & & 21 & 33.9 \\
$30-34$ & 42 & 26.3 & & 19 & 30.6 \\
$35-39$ & 6 & 3.8 & 2 & 3.2 \\
$40+$ & 12 & 7.5 & & 0 & \\
Total & 160 & & 62 & \\
\hline
\end{tabular}

Table 3. Routes of anabolic steroid administration

\begin{tabular}{lrr}
\hline Administered by & Total & $\%$ \\
\hline Tablet only & 15 & 24.2 \\
Injection only & 5 & 8.1 \\
Both & 42 & 67.7 \\
Total & 62 & 100.0 \\
\hline
\end{tabular}

Table 4. Anabolic steroids taken

\begin{tabular}{llrr}
\hline Drug & \multicolumn{1}{c}{$\begin{array}{c}\text { Means of } \\
\text { administration }\end{array}$} & No. & $\begin{array}{c}\text { \% of total } \\
\text { users }\end{array}$ \\
\hline Dianabol & Oral & 43 & 69.4 \\
Deca-Durabolin & Intramuscular & 37 & 59.7 \\
Testosterone & Oral, intramuscular & 32 & 51.6 \\
Stanozolol & Oral, intramuscular & 19 & 30.6 \\
Equipoise & Intramuscular & 10 & 16.1 \\
Diuretics & Oral & 10 & 16.1 \\
Thyroxine & Oral & 4 & 6.5 \\
Tamoxifen & Oral & 2 & 3.2 \\
\hline
\end{tabular}

the age range of responders is given in Table 2. Buckley et al. ${ }^{4}$ reported $38.1 \%$ of his study using both injectable and oral means of administration, whereas this study showed a $67.7 \%$ rate (Table 3 ), with $58 \%$ of anabolic steroid users having admitted injecting more than 30 times and $57 \%$ of users having injected in the past year. Two people had admitted using another user's syringe and needle, while six had lent their injecting equipment to another person. In all, 25 people had reported side-effects while using the drugs (40.3\% of anabolic steroid users). A total of 38 people (61\% of anabolic steroid users) acknowledged that the drugs were harmful, and one encouraging sign is that $55(89 \%)$ of the anabolic steroid users said they would make use of specialist advice if available. Table 4 shows the numbers of people who had taken the various drugs.

\section{Review of needle exchange schemes}

Telephone contact was made with those responsible for the needle exchange scheme (NES) statistics in Glamorgan as a whole. The question asked was what fraction of attenders at the NES were using the scheme solely for anabolic steroid abuse. The results, as shown in Table 5, vary from area to area. These figures are an underestimate, as it is known that
Table 5. Proportion of those attending needle exchange schemes for anabolic steroid use only

\begin{tabular}{lcc}
\hline & Nos. as a fraction of total attenders & \% of total attenders \\
\hline 1 & $26 / 60$ & 43.3 \\
2 & $80 / 220$ & 36.4 \\
3 & $15 / 200$ & 7.5 \\
4 & $3 / 106$ & 2.8 \\
\hline
\end{tabular}

attenders take and return syringes and needles for others.

\section{Discussion}

To anyone who attends gymnasia on a regular basis, it is not too difficult to see that the prevalence of anabolic steroid abuse has increased in the past two decades, but especially so in the last 5-10 years.

A response rate of $53.3 \%$ in such a study is one to be commended in view of the subject studied and its covert nature. The rate of use of $38.8 \%$ was consistent with the authors' suspicions and those in the relevant fraternities with whom the authors consulted before the study.

However, one problem which could be foreseen before undertaking the study was an assessment of the size of the denominator. It is to be hoped that our figure is realistic because managers and owners are well aware of the number of people attending their gymnasia as their income is a reflection of this.

The high proportion of steroid users who use both routes of administration indicates possible polypharmacy in these individuals and may reflect on what is available at different times.

With over $58 \%$ of those who have injected, injecting 30 times or more, one can assume that we are seeing committed anabolic steroid use. A similar figure of $57.4 \%$ of injectors admitted to injecting in the past year, showing that anabolic steroid misuse is a current issue. This is supported by the fact that $50 \%$ had taken oral anabolic steroids in the past year and $56.4 \%$ had taken tablets on 30 or more occasions.

An initial concern before undertaking the study was the possibility of HIV transmission from possible 'needle sharing' among individuals injecting anabolic steroids. As confirmed by the study, eight people had been involved in some form of needle sharing activity. Atkins ${ }^{5}$ claims that there could be a rapid spread of HIV among anabolic steroid users as needle sharing is becoming increasingly prevalent. Sklarek ${ }^{6}$ reported such a case in 1988 . Scott et al. ${ }^{7}$ also report a similar case. There is also some evidence from Atkins ${ }^{5}$ concerning the sharing of injecting equipment with amphetamine users in the Midlands. Another aspect of the injection problem is that some products are in ready-loaded syringes in a singledose form, thereby creating the possible problem of an inadequate means for disposal of used injecting equipment. Anabolic steroid users in our area are increasingly encouraged to use the NES available, to try to alleviate the above problems by a harm reduction programme. One side-effect of anabolic steroid misuse is an alteration of cholesterol metabolism in the form of decreased high-density lipoprotein levels and raised low-density lipoprotein levels ${ }^{8-10}$. 
This, taken together with another side-effect, i.e. hypertension, may sow the seeds for premature coronary artery disease and atherosclerosis. The long-term effects of prolonged anabolic steroid administration have not been determined in relation to atherosclerotic disease, but in a study of 29 athletes who died suddenly, three of the deaths were due to coronary artery disease ${ }^{11}$. Unfortunately the review did not address the possibility of anabolic steroid misuse as a contributory factor. Data from animal studies show that these drugs can also lead to changes in mitochondria and myofibrils of cardiac tissue $^{12,13}$. With this in mind, we may be seeing the start of premature coronary artery disease in these people.

It was refreshing to note that the study did not detect any anabolic steroid users under the age of 20 years as there is evidence from several studies that anabolic steroids can cause premature epiphyseal closure resulting in growth stunting ${ }^{14,15}$. What was not so reassuring was that $16 \%$ of users had used Equipoise (Squibb, Hounslow, UK; original drug no longer manufactured - only counterfeits available), which is a veterinary drug (Table 4).

As the results show, over $70 \%$ of people taking steroids do so for body building alone, and if grouped together with power lifting, form over $80 \%$ of all steroid-taking individuals. The people in the above fraternities need to recognize that even though they look far more healthy, and indeed feel more healthy, than the typical illicit drug abuser, if one shares injecting equipment for any drug, one is indulging in high-risk behaviour for HIV, and attendance at NES is encouraged. There are also other differences between the two groups of abusers, namely that the intravenous drug abuser appears to be better informed of the practical aspects of his habit (e.g. injecting technique), whereas anabolic steroid users do not appear to possess such an extensive knowledge (as experienced by those working at the NES). Anabolic steroid users usually request longer and bigger bore needles when attending NES, as some steroids are viscous and oil-based and a longer needle is preferred for intramuscular injection. Although needle sharing in the geographical area studied does not seem to be as prevalent as it could obviously be, we are currently participating in a poster campaign with a local NES, which has boosted attendance figures eightfold.

The reader may be puzzled to see diuretics, tamoxifen and thyroxine listed. Diuretics are used to achieve greater muscle definition by antagonizing the water retention which is sometimes seen as a side-effect of anabolic steroid use. Tamoxifen is used to prevent or control gynaecomastia, which can occur with anabolic steroid use. Thyroxine is taken to increase the body's metabolic rate.

At present, those people taking steroids rely on word-of-mouth advice of experienced steroid users and various handbooks.

The current notion of 'harm minimization', so prevalent in the illicit drugs field, should be broadened to include anabolic steroids, whereby NES should be made more accessible and users be made more aware of their existence.
General practitioners should try not to be immediately dismissive if they are approached by an individual who is intending to take or is taking steroids. The individual should obviously be made aware of the profession's view and its non-endorsement of anabolic steroid abuse, but this alone may not deter a keen potential, or established, anabolic steroid user. Counselling on the side-effects should be a widespread practice, and if a general practitioner is aware of an individual using anabolic steroids despite the above measures, then routine liver function tests, cholesterol, urea and electrolytes, full blood count and blood pressure measurement may be undertaken. If the individuals concerned can then see the biochemically adverse effects, it may assist in future abstinence or reduction of dosage or the number of drugs in the stack at one time Doctors should stress that because the individual feels and looks well, this does not necessarily equate with total body health.

One worrying problem is that polypharmacy is being used to counteract side-effects rather than giving up the anabolic steroid or even tailing down the dose; e.g. tamoxifen for gynaecomastia, Retin-A (Cilag, Sunderton, UK) cream for acne, diuretics for fluid retention, etc.

In the light of these findings, the medical profession should be made aware of the existence of anabolic steroid use and how to deal with it when confronted.

\section{References}

1 Corder BW, Dezelaky TL, Toohey JV et al. An analysis of trends in drug use behaviour at five American Universities. $J$ School Health 1974; 44: 386-9.

2 Corder BW, Dezelaky TL, Toohey JV et al. Trends in drug use behaviour at Central Arizona High Schools. Ariz J Health Phys Ed Recreation Dance 1975; 18: 10-11.

3 Newman M. Michigan Consortium of Schools Student Survey. Minneapolis Hazelden Research Services, 1986.

4 Buckley WE, Yesalis C, Friedl KE, Anderson WA, Streit AL Wright JE. Estimated prevalence of anabolic steroid use among male high school seniors. JAMA 1988; 260: 3441-5.

5 Atkins P. The power behind the muscle. Scoda Newsletter, July-August 1989.

6 Sklarek HM, Mantovani RP, Erens E, Heisler D, Niederman MS, Sein AM. A case of AIDS in a bodybuilder. N Engl J Med 1984; 311: 1701.

7 Scott MJ, Scott MJ Jr. HIV infection associated with injections of anabolic steroids. JAMA 1989; 262: 207-8.

8 Strauss RH, Wright JE, Finerman GAM. Anabolic steroid use and health status among 42 weight trained male athletes. Med Sci Sports Exerc 1982; 14: 119.

9 Haffner SM, Kushwaha RS, Foster DM. Studies on the metabolic mechanism of reduced high-density lipid protcins during anabolic steroid therapy. Metabolism 1983; 32: 413-20.

10 Webb OL, Laskarzewski PM, Glueck CJ. Severe depression of high-density lipoprotein cholesterol levels in weightlifters and bodybuilders by self-administered exogenous testosterone and anabolic-androgenic steroids. Metabolism 1984; 33: 971-5.

11 Maron BJ, Roberts WC, McAllister HA, Rosing DR, Epstein SE. Sudden death in young athletes. Circulation 1980; 62 : 218-29.

12 Behrendt $\mathrm{H}$, Boffin $\mathrm{H}$. Myocardial cell lesions caused by anabolic hormone. Cell Tissue Res 1977; 181: 423-6.

13 Behrendt $\mathrm{H}$. Effect of anabolic steroid on rat heart muscle cells, intermediate filament. Cell Tissue Res 1977; 180: 305-15.

14 Wilson JD, Griffin JE. The use and misuse of androgens. Metabolism 1980; 29: 1278-95.

15 Dorfman RI, Shipley RA. Androgens New York: John Wiley, 1956: 266. 